\section{Water Relations of Well-watered Citrus Exposed to Cold-acclimating Temperatures}

\author{
Smita Barkataky, Robert C. Ebel ${ }^{\mathbf{1}}$, and Kelly T. Morgan \\ University of Florida-Southwest Florida Research and Education Center, \\ 2685 SR 29 N, Immokalee, FL 34142-9515
}

\section{Keri Dansereau \\ Department of Horticulture, Auburn University, Auburn, AL 36849}

Additional index words. evapotranspiration, stem water potential, stomatal conductance, root resistance, osmotic potential, relative water content

\begin{abstract}
This study was conducted on well-watered citrus to determine changes in water relations during cold acclimation independent of drought stress. Potted sweet orange and Satsuma mandarin trees were exposed to progressively lower, non-freezing temperatures down to $10 / 4{ }^{\circ} \mathrm{C}$, light/dark temperatures, respectively, for 9 weeks in environmental growth chambers to promote cold acclimation. The trees were watered twice daily and three times on the day water relations data were collected to minimize drought stress. Although soil moisture was higher and non-limiting for plants in the cold than in the warm chamber, cold temperatures promoted stomatal closure, higher root resistance, lower stem water potential $\left(\Psi_{\text {stem }}\right)$, lower transpiration, and lower leaf $\psi_{\mathrm{s}}$. Leaf relative water content (RWC) was not different for cold-acclimated trees compared with the controls. Cold acclimation promoted stomatal closure at levels only observed in severely drought-stressed plants exposed to warm temperatures and where $\Psi_{\text {stem }}$ and RWC are typically much lower than what was found in this study. $\Psi_{\text {stem }}$ continued to decline the last 4 weeks of the experiment although air temperature, leaf $\psi_{s}$, RWC, stomatal conductance $\left(g_{S}\right)$, and transpiration were constant. The results of this experiment indicate that water relations of citrus during cold acclimation vary from those known to occur as a result of drought stress, which have implications for using traditional measures of plant water status in irrigation scheduling during winter.
\end{abstract}

Citrus regions in many parts of the world receive very little rainfall during winter and thus irrigation is considered essential. California accounts for $\approx 32 \%$ and Florida $65 \%$ of the total citrus production in the United States (Anonymous, 2012). Citrus grown in Florida receives very low rainfall during winter. Growers irrigate during winter based on evapotranspiration or soil moisture measurements with crop coefficients that range from 0.6 to 1.1 ; however, none of these methods incorporate changes in water requirements of citrus because they may change during cold acclimation independent of soil moisture content (Boman, 1994; Fares and Alva, 1999; Morgan et al., 2006). With water supplies in both regions limited, research is continuing to be conducted to optimize knowledge of water requirements.

Studies have typically concluded that citrus develop plant water deficits during winter (Ebel et al., 2004; Thomashow, 1999; Yelenosky, 1975, 1982, 1985). Most of these studies were conducted without adequate knowledge of soil moisture content or were conducted in dry soils that imposed drought

Received for publication 19 Mar. 2013. Accepted for publication 09 Aug. 2013.

${ }^{1}$ To whom reprint requests should be addressed; e-mail rcebel@ufl.edu. stress. Thus, it is not known how cold acclimation changes water relations of citrus independent of soil moisture content. Citrus cold-acclimate when air temperature is less than $10^{\circ} \mathrm{C}$, which typically occurs during winter in the citrus-growing regions of Florida and California (Attaway, 1997; Barkataky et al., 2012; Yelenosky, 1985; Yelenosky et al., 1984). There are several lines of evidence that would suggest that at least some changes in plant water deficits occur as a result of cold temperatures and not dry soil. Stomatal aperture and leaf water potential are typically reduced even on days of very low evaporative demand and after the trees have been fully irrigated (Ebel et al., 2004; Yelenosky, 1982).

Changes in citrus water relations during cold acclimation and independent of soil moisture content are not well understood. This study was conducted to characterize changes in plant relations of citrus plants with soil moisture carefully maintained at high levels to minimize drought stress. The results of this study are discussed with respect to implications for commercial irrigation of citrus during winter months as well as how the changes in plant water relations may be related more to freeze tolerance than plant water use.

\section{Materials and Methods}

Plant material and culture. Two experiments were conducted. The first experiment was conducted at the University of Florida's Southwest Florida Research and Education Center, Immokalee, FL, using sweet orange cv. Hamlin (Citrus sinensis L.) budded on Carrizo citrange $(C$. sinensis L. Osbeck $\times$ Poncirus trifoliata L. Raf.) rootstocks. The second experiment was conducted at Auburn University, Auburn, AL, using Satsuma mandarin [Citrus unshiu (Marc.) 'Owari'] budded on trifoliate orange rootstocks [Poncitrus trifoliata (L.) Raf. 'Rubidoux']. The treatments and data-collecting procedures were very similar for both experiments.

In the first experiment, the plants were grown in $20 \times 40-\mathrm{cm}(10.60-\mathrm{L})$ tree pots (manufactured by Steuwe and Sons Inc., Tangent, OR) filled with $11.79 \mathrm{~kg}$ of screened air-dried soil. The soil was Margate sand (siliceous, hyperthermic, mollic Psammaquents), which is typical of the Flatwoods region of southwestern Florida where citrus are commercially grown. Each pot was enclosed in fiberglass insulation to slow temperature declines of roots. The plants were fertilized once in a week with $500 \mathrm{~mL}$ of $33.6 \mathrm{~g}$ of a water-soluble fertilizer (Peters Professional, 18-8-17; Everris Int. B.V., Geldermalsen, The Netherlands) in 7.57 L of water. Keyplex 445, a combination of nitrate, iron manganese, and zinc (KeyPlex, Winter Park, FL), was applied as a foliar spray once every month. The pots were watered daily using a single 35 $\mathrm{mL} \cdot \mathrm{min}^{-1}$ drip irrigation emitter. The irrigation emitters were programmed to operate two times daily for $10 \mathrm{~min}$ at each watering. On the day data were collected, plants were watered three times to minimize drought stress.

In the second experiment, the plants were grown in 3.8-L pots in a one pine bark:onesand substrate by volume amended with $4.45 \mathrm{~kg} \cdot \mathrm{m}^{-3}$ of dolomite lime, $8.9 \mathrm{~kg} \cdot \mathrm{m}^{-3}$ of $18 \mathrm{~N}-6 \mathrm{P}_{2} \mathrm{O} 5-12 \mathrm{~K}_{2} \mathrm{O}$, (Polyon 12-14 month controlled release fertilizer; Pursell Technologies, Inc., Sylacauga, AL), and $0.89 \mathrm{~kg} \cdot \mathrm{m}^{-3}$ of a micronutrient package (Micromax; The Scotts Co., Marysville, OH). All plants were supplemented with water-soluble $20 \mathrm{~N}-$ $20 \mathrm{P}_{2} \mathrm{O}_{5}-20 \mathrm{~K}_{2} \mathrm{O}$ with micronutrients, which were applied at $234 \mathrm{mg} \cdot \mathrm{L}^{-1}$ when watered. Each pot was enclosed in fiberglass insulation to slow temperature declines of roots. The plants were watered when soil moisture dropped below $85 \%$ of the water-holding capacity of the substrate except on days when data were collected. The temperature of the water used to water the plants was $\approx 20{ }^{\circ} \mathrm{C}$.

Temperature treatments. Both experiments were provided with the same temperature treatments. Two temperature treatments were imposed on plants in two identical environmental growth chambers (Model PGR 15; Conviron Products of America, Pembina, $\mathrm{ND}$, for the first experiment and Model E15; Conviron, Winnipeg, Canada, for the second experiment). The temperature treatment for coldacclimated plants was $25{ }^{\circ} \mathrm{C}$ day $/ 20^{\circ} \mathrm{C}$ night for $7 \mathrm{~d} ; 20^{\circ} \mathrm{C}$ day $/ 15^{\circ} \mathrm{C}$ night for $7 \mathrm{~d} ; 15^{\circ} \mathrm{C}$ day $/$ $10{ }^{\circ} \mathrm{C}$ night for $7 \mathrm{~d}$; and $10^{\circ} \mathrm{C}$ day $/ 5^{\circ} \mathrm{C}$ night for $42 \mathrm{~d}$. The irradiance was $450 \mu \mathrm{mol} \cdot \mathrm{m}^{-2} \cdot \mathrm{s}^{-1}$. The temperatures were lowered after water relations data collection. In the control growth 
chamber, air temperature was maintained at $25{ }^{\circ} \mathrm{C}$ day $/ 20{ }^{\circ} \mathrm{C}$ night throughout the experiment. The day/night photoperiod for both treatments was $12 \mathrm{~h} / 12 \mathrm{~h}$, respectively.

Data collected. Data were collected every $7 \mathrm{~d}$. On the days data were collected and 2 to $4 \mathrm{~h}$ after the start of the light period, the pots were thoroughly watered as demonstrated by water flowing from the bottom of the pots. Gravitational water was allowed to percolate out of the pots for $2 \mathrm{~h}$ before $g_{\mathrm{S}}$ and transpiration measurements were taken.

Stomatal conductance and transpiration. Stomatal conductance and transpiration data were obtained for both experiments on five recently matured leaves using a steady state porometer (Model LI 1600; LI- COR Inc., Lincoln NE) and a portable photosynthesis system (Model 6400; LI-COR Inc.).

Stem water potential. $\Psi_{\text {stem }}$ was measured for both the first and the second experiments. Immediately after watering the pots and before $g_{\mathrm{S}}$ measurements were taken, one leaf per plant in the first experiment and two leaves per plant in the second experiment were wrapped in flexible plastic and aluminum foil (Garnier and Berger, 1985). The water potential of the leaf was allowed to equilibrate with the stem for $2 \mathrm{~h}$ before the leaves were excised and water potential measured using a pressure chamber (Model 3005 plant water status console; Soil Moisture Equipment Corporation, Santa Barbara, CA).

Osmotic potential. $\Psi_{\pi}$ was measured in the first experiment. Immediately after measuring $\Psi_{\text {stem }}$, a 7-mm diameter disk was cut from each leaf using a cork borer, immediately dipped into liquid nitrogen, and held at $-80{ }^{\circ} \mathrm{C}$ until measurement. Osmotic potential of each leaf disk was determined using a Dew Point Microvoltmeter (Model HR-33 T; Wescor, Inc., Logan, UT) that was calibrated with $0.550,0.157$, and $0.053 \mathrm{~m}$ solutions of $\mathrm{NaCl}$ of known $\psi_{\mathrm{S}}$ of $-2.5,-0.75$, and $-0.25 \mathrm{MPa}$, respectively.

Relative water content. RWC was measured in the first experiment. After removing the leaf core used to determine $\Psi_{\pi}$, the leaves were immediately weighed to determine fresh weight $(\mathrm{FW})$. The leaves were rehydrated by floating upright on water at $4{ }^{\circ} \mathrm{C}$ for $24 \mathrm{~h}$, blotted dry with paper towels, and weighed to determine the turgid weight (TW). The leaves were dried at $54{ }^{\circ} \mathrm{C}$ for $72 \mathrm{~h}$ and weighed to determine dry weight (DW). RWC was calculated as $\mathrm{RWC}=[(\mathrm{FW}-\mathrm{DW}) /(\mathrm{TW}-$ DW) $] \times 100$.

Estimation of root resistance. Root resistance $\left(\mathrm{R}_{\text {root }}\right)$ was estimated for both experiments using the same approach. Water movement in the soil-plant atmosphere continuum can be described using an analogy of Ohm's law (Landsberg and Jones, 1981; Van den Honert, 1948), which describes flow as being proportional to the driving force and inversely proportional to the resistance in the flow path:

$$
T=\frac{\left(\psi_{\text {soil }}-\psi_{\text {stem }}\right)}{\left(R_{\text {root }}+R_{\text {soil }}\right)}
$$

where $\mathrm{T}$ is whole plant transpiration, $\Psi_{\text {soil }}$ is soil water potential, $\Psi_{\text {stem }}$ is stem water potential, $R_{\text {root }}$ is root resistance, and $R_{\text {soil }}$ is the resistance of water movement from the soil to the root surface. $R_{\text {root }}$ of each plant was calculated by rearranging Eq. [1]:

$$
R_{\text {root }}=\left[\frac{\left(\psi_{\text {soil }}-\psi_{\text {stem }}\right)}{T}\right]-R_{\text {soil }}
$$

It was assumed that $\Psi_{\text {soil }}$ was zero, which is very close to values typical for soils at waterholding capacity (Mengel et al., 2001; Paul, 2007). $R_{\text {soil }}$ was assumed to be zero, which is a reasonable assumption for well-watered soils (Malazian et al., 2011). These assumptions allowed Eq. [2] to be simplified to:

$$
R_{\text {root }}=\frac{-\psi_{\text {stem }}}{T}
$$

Whole plant transpiration (T) was calculated by:

$$
T=\frac{\left(P W_{o}-P W_{t}\right) / A_{\text {leaf }}}{t}
$$

where $\mathrm{PW}_{\mathrm{o}}$ was pot weight $(\mathrm{g})$ measured $2 \mathrm{~h}$ after watering, $\mathrm{PW}_{\mathrm{t}}$ was pot weight $(\mathrm{g})$ measured $\approx 4 \mathrm{~h}$ later, $\mathrm{A}_{\text {leaf }}$ is the total leaf area of the plant $\left(\mathrm{m}^{2}\right)$, and $\mathrm{t}$ is the time elapsed between weight measurement (s). $\mathrm{T}$ was multiplied by $1 \times 10^{-6} \mathrm{~m}^{-3} \cdot \mathrm{g}^{-1}$, the inverse of water density, to convert transpiration units from weight $\left(\mathrm{g} \cdot \mathrm{m}^{-2} \cdot \mathrm{s}^{-1}\right)$ to volume $\left(\mathrm{m}^{3} \cdot \mathrm{m}^{-2} \cdot \mathrm{s}^{-1}\right)$ and thus give $\mathrm{R}_{\text {root }}$ units of $\mathrm{MPa} \cdot \mathrm{s}^{1}$, units that are commonly used to describe root hydraulic resistance (Kriedemann and Barrs, 1981; Landsberg and Jones, 1981). The morning after all other measurements were taken, the potting media was refilled to water-holding capacity and after gravitational water was allowed to percolate from the base of the pots the pots were weighed to find $\mathrm{PW}_{\mathrm{o}}$ and reweighed $\approx 4 \mathrm{~h}$ later to find $\mathrm{PW}_{\mathrm{t}}$. After measuring $\mathrm{PW}_{\mathrm{t}}$, the temperature in the coldacclimated plants was lowered to impose the next temperature treatment.

Leaf area. Leaf area was measured at the beginning of each of the experiments using a portable leaf area meter (Model LI-3000A; LI-COR Inc.). Because the trees were growing when the experiment was initiated, each growing tip was labeled. At the end of the experiment, leaves of new growth were removed separately from leaves that were present before the experiment was initiated and total leaf area of each was measured separately. Total leaf area on the day water relations data were collected was estimated by adding the initial leaf area to an estimate of leaf area of new growth. Leaf area of new growth was estimated by assuming a linear growth rate for the entire treatment period for control plants and for the first 3 weeks for the acclimated plants after which growth had stopped. Growth of plants typically occurs in three phases: an early accelerating phase, a linear phase, and a growth termination phase (Erickson, 1976; Yin et al., 2003). The plants in the current study were in the middle of a typical growth flush and thus were assumed to be in the linear growth phase. Area of leaves used for $\Psi_{\text {stem }}$ measurements were also measured after FW measurement and subtracted from the total leaf area present when the experiment was initiated.

Soil moisture. Soil moisture was measured for the first experiment. To verify that soil moisture was not limiting for plants in the cold-acclimated chamber on the day data were collected, soil moisture was measured every 5 min on two sweet orange plants using dielectric aquameter sensors (ECHO; Decagon Devices, Inc., Pullman, WA) and a data logger (HOBO micro station Model H21 002; Decagon Devices, Inc., Pullman, WA).

Statistical analysis. There were eight plants used per treatment in each experiment. Means were separated using $2 \times$ the SEM.

\section{Results}

Soil moisture in the cold-acclimated chamber remained nearly constant during the $4 \mathrm{~h}$ that plant water relations measurements were made, whereas soil moisture in pots with control plants declined to $\approx 0.11 \mathrm{~m}^{3} \cdot \mathrm{m}^{-3}$ (Fig. 1). The amount of water removed in the control treatment would not have imposed significant drought stress (Morgan et al., 2006). Leaf RWC was similar for both cold-acclimated and unacclimated plants throughout the experiment (Fig. 2A).

Despite the well-watered conditions for cold-acclimated plants, changes in water relations typically found in drought stress plants occurred. Transpiration declined close to zero by the third week for C. sinensis (Fig. 3A) and the seventh week for C. unshiu (Fig. 3B). Transpiration remained low at the coldest temperatures in part because of stomatal closure (Fig. 3C-D), but evaporative demand was also less in the cold acclimation chamber as shown previously (Barkataky et al., 2013). Citrus stomates completely close only under extreme drought stress (Kriedemann and Barrs, 1981). $\Psi_{\text {stem }}$ declined in a linear manner throughout the experiment for cold-acclimated plants to $\approx-0.9 \mathrm{MPa}$ for $C$. sinensis (Fig. 3E) and $-1.2 \mathrm{MPa}$ for $C$. unshiu (Fig. 3F), which is typical for plants exposed to mild drought stress (Chone et al., 2001; Naor, 2000; Stagno et al., 2011). $\Psi_{\text {stem }}$ of the unacclimated controls remained between -0.4 and $-0.5 \mathrm{MPa}$, which is typical for citrus plants exposed to well-watered conditions and under very low evaporative demand (Chone et al., 2001; Naor,

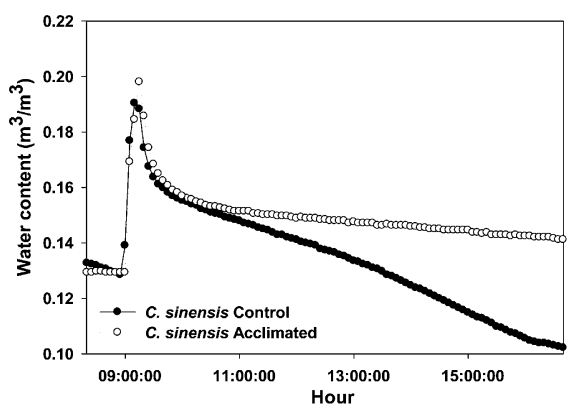

Fig. 1. Soil moisture content of potted $C$. sinensis trees on a day water relations measurements were collected. Data are means of two trees per treatment. 


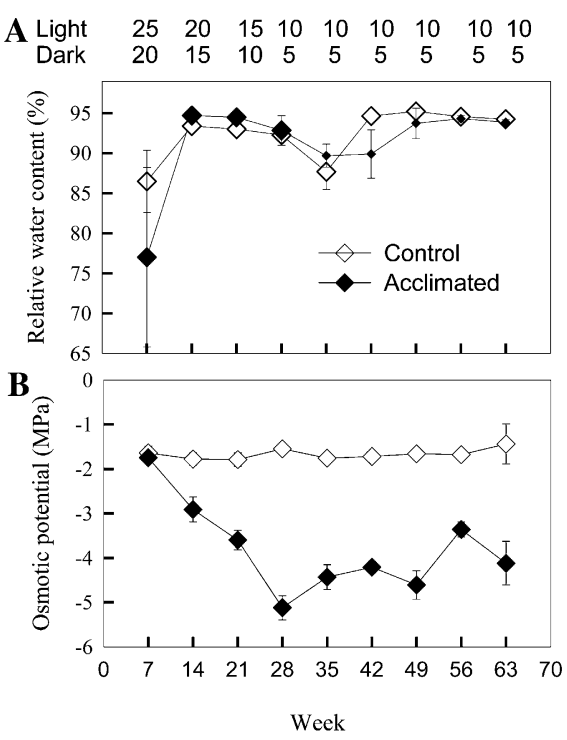

Fig. 2. Leaf relative water content (A) and osmotic potential $\left(\psi_{\mathrm{S}}\right)(\mathbf{B})$ of $C$. sinensis exposed to cold-acclimating temperatures and warm temperatures that minimize cold acclimation and promote growth (control). Temperatures of the cold acclimation treatment are shown at the top of the figure $\left({ }^{\circ} \mathrm{C}\right)$ during the light $(12 \mathrm{~h})$ and dark $(12 \mathrm{~h})$ cycles.

2000; Stagno et al., 2011). The $\Psi_{\pi}$ of coldacclimated $C$. sinensis trees decreased to a minimum of $-5.3 \mathrm{MPa}$ by the fourth week and remained between -5.3 and $-3.8 \mathrm{MPa}$ when exposed to $10 / 5{ }^{\circ} \mathrm{C}$, whereas the controls remained between -1.0 and $-2.0 \mathrm{MPa}$ (Fig. 2B). Syvertsen et al. (1988) reported $\Psi_{\pi}$ values of -2.16 and $-2.27 \mathrm{MPa}$ for trifoliate orange and sweet orange, respectively, when exposed to drought stress for $60 \mathrm{~d}$.

Cold acclimation increased $\mathrm{R}_{\text {root }}$ by six times in C. sinensis (Fig. 3G) and by $18 \%$ in C. unshiu (Fig. $3 \mathrm{H}$ ) by the end of the experiment compared with control plants. Some error may have been introduced in the control trees by assuming $\mathrm{R}_{\text {soil }}$ was zero, but any error would have led to lower $R_{\text {root }}$ estimates, which would have accentuated the difference in $\mathrm{R}_{\text {root }}$ between the cold-acclimated and unacclimated control trees. The $\mathrm{R}_{\text {root }}$ values are typical for citrus as reported previously (Elfving et al., 1972; Ramos and Kaufmann, 1979; Wilcox and Davies, 1981; Wilcox et al., 1983) and these resistances are similar to those of droughtstressed citrus (Kriedemann and Barrs, 1981).

\section{Discussion}

Our modern understanding of plant water relations has mainly evolved from studying growing plants at warm temperatures and in soils of varying moisture contents. It is understandable then that as studies have been conducted on cold-acclimated plants, the traditional relationships among water relation parameters of drought-stressed plants would be made. However, this study demonstrates that those relationships are not consistent for citrus trees exposed to cold-acclimating temperatures. By carefully maintaining high soil
Citrus sinensis

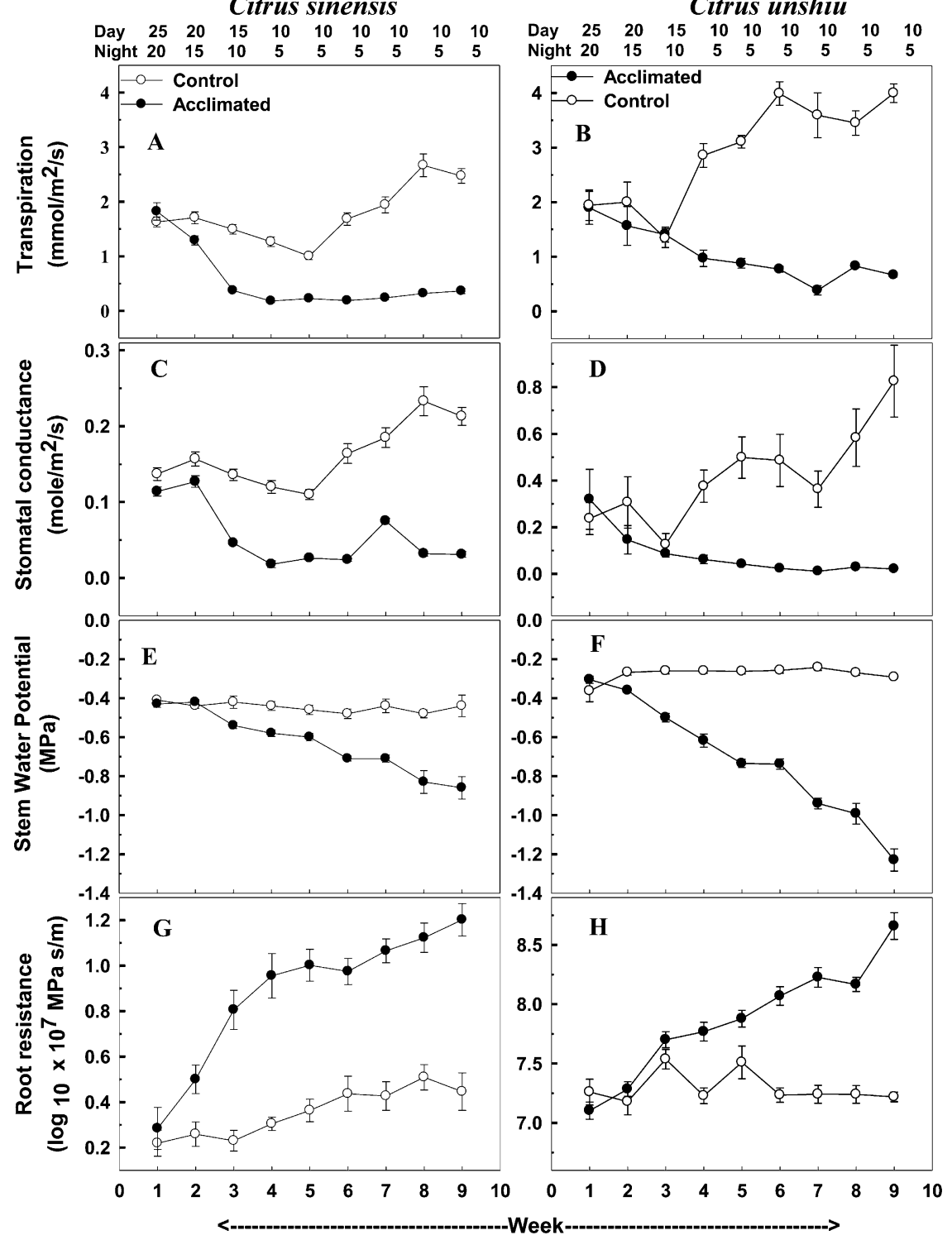

Fig. 3. Transpiration, stomatal conductance $\left(g_{\mathrm{S}}\right)$, stem water potential, and root resistance of the coldacclimated and the unacclimated (control) Citrus sinensis $(\mathbf{A}, \mathbf{C}, \mathbf{E}, \mathbf{G})$ and Citrus unshiu $(\mathbf{B}, \mathbf{D}, \mathbf{F}, \mathbf{H})$ during cold acclimation. Temperatures of the cold acclimation treatment are shown at the top of the figure $\left({ }^{\circ} \mathrm{C}\right)$ during the light $(12 \mathrm{~h})$ and dark $(12 \mathrm{~h})$ cycles.

moisture contents throughout the experiments and especially on the day measurements were made, drought stress was minimized as evidenced by maintaining soil moisture near the water-holding capacity of the potting media and which was confirmed by the very high $\Psi_{\text {stem }}$ of plants in the warm chamber. Thus, any changes in water relations of plants in the cold chamber would be mainly the result of temperature and not drought stress and should be considered with respect to the development of freeze tolerance.

Cold temperatures promoted stomatal closure, higher $\mathrm{R}_{\text {root}}$, lower $\Psi_{\text {stem }}, \Psi_{\pi}$, and very low transpiration. Some of the changes we found in the current study have been shown in other studies and thus it is not surprising that others have concluded that cold acclimation promotes plant water deficits (Ebel et al., 2004; Kriedemann and Barrs, 1981; Huang et al., 2011; Yelenosky, 1978, 1982; Young, 1970; Young and Peynado, 1965) because even under the well-watered conditions of this study, most of the water relation parameters changed in a manner consistent with the development of plant water deficits. Nevertheless, there are some striking inconsistencies in water relation parameters compared with those found in drought-stressed citrus plants. Stomatal closure, high $\mathrm{R}_{\text {root }}$, the low $\Psi_{\pi}$, and very low transpiration are at levels that occur for only extremely drought-stressed citrus trees (Kriedemann and Barrs, 1981), yet the $\Psi_{\text {stem }}$ and RWC values are typical for actively growing, well-watered trees grown in commercial grove situations on warm, sunny days (Kriedemann and Barrs, 1981).

Because the changes in plant water relations are not related to soil moisture, we conclude that these changes are adaptive mechanisms that increase tolerance to freezes, although how these changes relate to freeze tolerance cannot be deduced from these data. Nevertheless, several interesting relationships should 
be noted. First, $\Psi_{\text {stem }}$ of Satsuma mandarin was lower than sweet orange on each measuring date although air temperature was the same. Satsuma mandarin is also substantially more cold-hardy than sweet orange (Yelenosky, 1985). Second, $\Psi_{\text {stem }}$ continued to decline throughout the study for both genotypes even for the last 5 weeks when air temperature, soil moisture content, and $\Psi_{\pi}$ were relatively constant. Although 3 weeks at low temperature have been suggested as being optimum for promoting maximum cold-hardiness of citrus (Yelenosky et al., 1984), it appears that $\Psi_{\text {stem }}$ continues to change and may indicate a deeper level of acclimation beyond 3 weeks. Third, $\Psi_{\pi}$ reached a minimum by the fourth week of cold acclimation and may indicate the limit to the accumulation of osmotically active substances (Cuilan et al., 2000; Kushad and Yelenosky, 1987; Ligeng et al., 2000; Lin and Liu, 1994; Lin et al., 1994; Yelenosky, 1985). Fourth, the decline in $\Psi_{\text {stem }}$ beyond the fourth week of cold acclimation cannot be related to $\Psi_{\pi}$, which remained relatively constant during this same time period. Fifth, stomates closed reducing transpiration to close to zero although RWC remained high. We can conclude that the plant does not open stomates sufficiently to allow some drying that would reduce RWC.

The results from this study may have implications for commercial grove managers in managing irrigation during winter. However, it must be considered that the current study was conducted for potted plants where the roots were exposed to the same temperatures as the shoots, a phenomenon that rarely occurs in nature where soil temperatures are normally warmer during winter than air temperature as a result of heat storage of the soil and bedrock. In regions where freezes occur and irrigation is required, deficit irrigation is recommended to impose mild drought stress to promote cold acclimation (Besigner, 2004), but how overlaying drought stress on the changes that are associated with air temperatures that promote cold acclimation are not known. Current irrigation scheduling methods generally incorporate only evaporative demand and soil moisture measurements (Morgan et al., 2009). Changes that occur in citrus that affect water use during cold acclimation are ignored and as such lead to excessive irrigation (Barkataky et al., 2013). Some have proposed using $\Psi_{\text {leaf }}$ or $\Psi_{\text {stem }}$ measurements for irrigation scheduling (Ortũno et al., 2006; Shackel et al., 1997), but their modification, independent of soil moisture status during cold acclimation, would have to be considered during winter for citrus.

\section{Literature Cited}

Anonymous, 2012.United States Department of Agriculture. National Agricultural Statistics Service. Sept. 2011. ISSN: 1948-9048.

Attaway, J.A. 1997. A history Florida citrus freezes. Florida Science Source, Inc., Lake Alfred, FL.

Barkataky, S., K.T. Morgan, and R.C. Ebel. 2013. Plant water requirement of 'Hamlin' sweet orange in cold temperature conditions. Irrig. Sci. 31:431-443.

Besigner, A.R. 2004. Evaluation of the effects of two deficit irrigation strategies on vitis vinifera 'Cabernet Sauvignon' yield. Fruit composition, cold acclimation, and hardiness. MS thesis, Texas Tech University, Lubbock, TX.

Boman, B.J. 1994. Evapotranspiration by young Florida flatwoods citrus trees. J. Irrig. Drain. Eng. 120:80-88.

Chone, X., C.V. Leeuwen, D. Dubourdieu, and J.P. Gaudillere. 2001. Stem water potential is a sensitive indicator of grapevine water status. Ann. Bot. (Lond.) 87:477-483.

Cuilan, M., L. Xinghui, and H. Youli. 2000. The correlation of osmoregulation substances and water states with cold tolerance in Guianxi pummel. J. Fujian Agr. Univ. 29:31-34.

Ebel, R.C., P.A. Carter, W.A. Dozier, D.A. Findley, M.L. Nesbitt, B.R. Hockema, and J.L. Sibley. 2004. Pattern of exotherm and electrolyte leakage measured at high frequency of Satsuma mandarin exposed to subfreezing temperatures. HortScience 39:1614-1616.

Elfving, D.C., K.R. Kaufmann, and A.E. Hall. 1972. Interpreting leaf water potential measurements with a model of soil-plant-atmosphere continuum. Physiol. Plant. 271:16-168.

Erickson, R.O. 1976. Modeling of plant growth. Annu. Rev. Plant Physiol. 27:407-434.

Fares, A. and A.K. Alva. 1999. Estimation of citrus evapotranspiration by soil water mass balance. Soil Sci. 164:302-310.

Garnier, E. and A. Berger. 1985. Testing water potential in peach trees as an indicator of water stress. J. Hort. Sci. 60:47-56.

Huang, Y., Y. Si, and F. Dane. 2011. Impact of grafting on cold responsive gene expression in Satsuma mandarin (Citrus unshiu). Euphytica 177:25-32.

Kriedemann, P.E. and H.D. Barrs. 1981. Citrus orchards, p. 325-416. In: Kozlowski, T.T. (ed.). Water deficits and plant growth, Chapter 5, Vol. VI. Academic Press, New York, NY.

Kushad, M. and G. Yelenosky. 1987. Evaluation of polyamine and Proline levels during low temperature acclimation of citrus. Plant Physiol. 84:692-695.

Landsberg, J.J. and H.G. Jones. 1981. Apple orchards, p. 419-460. In: Kozlowski, T.T. (ed.). Water deficits and plant growth, Chapter 6, Vol. VI. Academic Press, New York, NY.

Ligeng, C., H. Xiqin, and S. Lixiao. 2000. Studies on cold tolerance in navel orange strains. J. Zhejiang Univ. 26:505-508.

Lin, D.B. and Z.Q. Liu. 1994. Effect of cold acclimatization and ABA on membrane stability and synthesis of membrane protein in citrus. J. Nanjing Agr. Univ. 17:1-5.

Lin, D.B., Z.Q. Liu, and S.C. Zhang. 1994 Effects of polyamines on cold hardiness development of citrus. Acta Hort. Sinica 21:222226.

Malazian, A., P. Hartsough, T. Kamai, G.S. Campbel, D.R. Cobos, and J.W. Hopmans. 2011. Evaluation of MPS-1 soil water potential sensor. J. Hydr. 402:126-134.

Mengel, K., E.A. Kirkby, H. Kosegarten, and T. Appel. 2001Principles of plant nutrition. 5th Ed. Kluwer Academic Publishers, Dordrecht, The Netherlands.

Morgan, K.T., E.A. Hanlon, and T.A. Obreza. 2009. A web-based irrigation scheduling model to improve water use efficiency and reduce nutrient leaching for Florida vitrus. SL 286. Soil and Water Science Department, Florida Cooperative Extension Service, Institute of
Food and Agricultural Sciences, University of Florida, Gainesville, FL.

Morgan, K.T., T.A. Obreza, J.M.S. Scholberg, L.R. Parsons, and T.A. Wheaton. 2006. Citrus water uptake dynamics on a sandy Florida entisol. Soil Sci. Soc. Amer. J. 70:90-97.

Naor, A. 2000. Midday stem water potential as a plant water stress indicator for irrigation scheduling in fruit trees. Acta Hort. 537:447-454.

Ortũno, M.F., Y. García-Orellana, W. Conejero, M.C. Ruiz-Sánchez, J.J. Alarcón, and A. Torrecillas. 2006. Stem and leaf water potentials, gas exchange, sap flow, and trunk diameter fluctuations for detecting water stress in lemon trees. Trees 20:1-8.

Paul, E.A. 2007. Soil microbiology, ecology, and biochemistry. Academic Press, MA.

Ramos, C. and M.R. Kaufmann. 1979. Hydraulic resistance of rough lemon roots. Physiol. Plant. 45:311-314.

Shackel, K.A., H. Ahmadi, W. Biasi, R. Buchner, D. Goldhamer, S. Gurusinghe, J. Hasey, D. Kester, B. Krueger, B. Lampinen, G. McGourty, W. Micke, E. Mitcham, B. Olsen, K. Pelletrau, H. Philips, D. Ramos, L. Scheankl, S. Sibbert, R. Snyder, S. Southwick, M. Stevenson, M. Thorpe, S. Weinbaum, and J. Yeager. 1997. Plant water status as an index of irrigation need in deciduous fruit trees. HortTechnology 7:23-29.

Stagno, F., A. Giuffrida, and F. Intrigliolo. 2011. Canopy temperature as an indicator of water status in citrus trees. In: Proc. of the 6th International Symposium on Irrigation of Horticultural Crops. Acta Hort. 889.

Syvertsen, J.P., J. Lloyd, and P.E. Kriedemann. 1988. Salinity and drought stress effects on foliar ion concentration, water relations, and photosynthetic characteristics of orchard citrus. Aust. J. Agr. Res. 39:619-627.

Thomashow, M.F. 1999. Plant cold acclimation: Freezing tolerance genes and regulatory mechanisms. Annu. Rev. Plant Physiol. Plant Mol. Biol. 50:571-599.

Van den Honert, T.H. 1948. Water transport in plants as a catenary process. Discuss. Faraday Soc. 3:146-153.

Wilcox, D.A. and F.S. Davies. 1981. Temperaturedependent and diurnal root conductivities in two citrus rootstocks. HortScience 16:303-305.

Wilcox, D.A., F.S. Davies, and D.W. Buchanan. 1983. Root temperature, water relations, and cold hardiness in two citrus rootstocks. J. Amer. Soc. Hort. Sci. 108:318-321.

Yelenosky, G. 1975. Cold hardening in citrus stems. Plant Physiol. 56:40-543.

Yelenosky, G. 1978. The effect of withholding water on cold hardiness of 'Valencia' orange and 'Star Ruby' grapefruit trees in controlled freezes. Proc. Fla. State Hort. Soc. 91:18-20.

Yelenosky, G. 1982. Indicator of citrus cold-hardening in the field. Proc. Fla. State Hort. Soc. 95:7-10.

Yelenosky, G. 1985. Cold hardiness in citrus. Hort. Rev. 7:201-238.

Yelenosky, G., C.J. Hearn, and D.J. Hutchison. 1984. Nonhardening temperatures-Major factors in freeze damage to citrus trees in Dec. 1983. Proc. Fla. State Hort. Soc. 97:33-36.

Yin, X., J. Goudrian, E.A. Lantinga, J. Vos, and H.J. Spiertz. 2003. A flexible sigmoid function of determinate growth. Ann. Bot. (Lond.) 91:361-371.

Young, R. 1970. Induction of dormancy and cold hardiness in citrus. HortScience 5:411-413.

Young, R.H. and A. Peynado. 1965. Changes in cold hardiness and certain physiological factors of Redblush grapefruit seedlings as affected by exposure to artificial hardening temperatures. Proc. Amer. Soc. Hort. Sci. 86:244-252. 